\title{
Efektivitas Fitobiotik Bawang Putih Terfermentasi terhadap Produktivitas Ayam Broiler
}

\section{The Effectiveness of Phytobiotic Fermented Garlic on Broiler Productivity}

\author{
D. Siswantoro ${ }^{1}$, A. F. Prasetyo ${ }^{1}$, dan S. B. Kusuma ${ }^{2 *}$ \\ ${ }^{1}$ Program Studi Manajemen Bisnis Unggas, Jurusan Peternakan, Politeknik Negeri Jember, Jl. Mastrip PO \\ Box 164, Jember, Jawa Timur, Indonesia \\ ${ }^{2}$ Program Studi Produksi Ternak, Jurusan Peternakan, Politeknik Negeri Jember, Jl. Mastrip PO Box 164, \\ Jember, Jawa Timur, Indonesia \\ *Corresponding E-mail: satriabudikusuma@polije.ac.id \\ (Diterima:6 Oktober 2020; Disetujui: 27 Januari 2021)
}

\begin{abstract}
ABSTRAK
Penelitian ini bertujuan untuk menentukan kemampuan dari Alternative Natural Growth Promotors (ANGP) yaitu probiotik dan fitobiotik (ProPhyto) terhadap produktivitas ayam broiler. Komposisi ANGP yaitu terdiri dari fermentasi bawang putih yang menggunakan probiotik dari usus halus sapi. Penelitian ini menggunakan 200 ekor ayam broiler, pada umur 15 hari mulai diberikan profitobiotik dengan dosis masing-masing kelompok; $0 \mathrm{ml} /$ liter, $2 \mathrm{ml} / \mathrm{ltr}, 4 \mathrm{ml} /$ liter, dan $6 \mathrm{ml} /$ liter dari air minum yang diberikan sampai umur 35 hari. Profitobiotik yang digunakan memiliki total konsentrasi bakteri sejumlah $6,32 \mathrm{x}$ $107 \mathrm{CFU} / \mathrm{ml}$ dan mengandung 8,38 x $106 \mathrm{CFU} / \mathrm{ml}$ bakteri asam laktat. Penelitian ini menggunakan metode analisis rancang acak lengkap (RAL) dengan 4 perlakuan dan 5 pengulangan, data yang diperoleh kemudian dianalisis secara statistik, bila terdapat beda nyata maka akan diuji lanjut. Parameter yang diukur meliputi: penampilan, bobot dan persentase karkas, persentase lemak abdominal dan hati. Hasil penelitian menunjukan bahwa penampilan ayam broiler (konsumsi pakan, pertambahan bobot badan, dan konversi pakan) menunjukkan hasil yang tidak berbeda nyata $(\mathrm{P}>0,05)$, hal yang sama juga terlihat pada hasil bobot badan, persentase karkas, persentase lemak hati, persentase susut masak, dan daya ikat air $(\mathrm{P}>0,05)$. Hasil yang signifikan $(\mathrm{P}<0,05)$ terlihat pada persentase lemak abdominal dan tekstur (keempukan) daging broiler. Hasil dari penelitian tidak menunjukkan efek negatif terhadap produktivitas broiler bahkan menunjukkan penggunaan profitobiotik memberikan efek yang menguntungkan terhadap kesehatan ayam broiler dan meningkatkakn karkas dengan cara mengurangi lemak abdominal. Penggunaan dosis 2 dan 4 ml/liter dari air minum efektif menjaga produktivitas ayam broiler dan mengurangi penggunaan antibiotik dan obatobatan. Hal ini mengarahkan pada daging ayam broiler yang lebih sehat dan aman bagi konsumen.
\end{abstract}

Kata kunci: bawang putih, fitobiotik, probiotik, ayam broiler, penampilan

\section{ABSTRACT}

This study aims to determine the ability of Alternative Natural Growth Promotors (ANGP), namely probiotics and phytobiotics (ProPhyto), to broiler productivity. ANGP ingredients are made by fermenting garlic with probiotics from the small intestine of cattle. In this study, 200 chickens aged 15 days were given a prophytobiotic dose (ProPhyto) of $0 \mathrm{ml} / \mathrm{liter}, 2 \mathrm{ml} / \mathrm{ltr}, 4 \mathrm{ml} / \mathrm{liter}$, and $6 \mathrm{ml} /$ liter of drinking water per day for up to 35 days. The prophytobiotics used had a total bacterial concentration of $6.32 \times 107 \mathrm{CFU} / \mathrm{ml}$ and contained $8.38 \times 106 \mathrm{CFU} / \mathrm{ml}$ of lactic acid bacteria. The study was conducted with a Randomized Complete Design method with four treatments and five replications. The data obtained will be analyzed statistically and different tests if there are significant or very significant differences. Parameters measured include performance, weight, percentage of the carcass, percentage of abdominal fat, and liver. The results showed that broiler performance (feed consumption, body weight gain, and feed conversion) gave no significant difference in effect $(P>0.05)$, as well as weight, percentage of the carcass, percentage of the liver, percentage cooking loss, and water holding capacity $(P>0.05)$. A significant effect $(P<0.05)$ was shown on the percentage of abdominal fat and texture (tenderness) broiler meat. The results of the study 
did not show the negative effects of broiler productivity. They even indicated that the use of prophytobiotics could provide positive benefits to the health of broilers and improve carcasses by reducing the content of abdominal fat. Use at doses of 2 and $4 \mathrm{ml} /$ liter of drinking water is effective in maintaining broiler productivity and reducing the use of antibiotics as well as medicinal chemicals. It leads to broiler meat that is healthier and safer for consumers.

Keywords: garlic, phytobiotic, probiotic, broiler chicken, performance

\section{PENDAHULUAN}

Perkembangan ayam ras pedaging (broiler) di Indonesia telah menjadi salah satu komoditas utama penyedia protein hewani bagi masyarakat. BPS (2019) telah mencatat bahwa populasi ayam ras pedaging di Indonesia mencapai 3.149.382.220 ekor. Kondisi tersebut merupakan salah satu indikator bahwa ayam ras pedaging merupakan penyedia kebutuhan protein hewani berupa daging yang paling digemari oleh masyarakat Indonesia. Namun di sisi lain, pemanfaatan ayam ras pedaging menyimpan resiko bagi konsumen, karena penggunaan berbagai jenis antibiotik. Antibiotik yang berfungsi sebagai terapeutik terserap dengan baik oleh tubuh ayam sebagai pencegahan penyakit, namun juga akan dapat berakibat buruk karena meningkatkan pula resistensi ternak terhadap berbagai jenis mikroorganisme patogen tertentu.

Pelarangan terhadap penggunaan AGP (Antibiotic Growth Promoters) telah menjadi standar internasional. Penggunaan antibiotik menjadi kebutuhan peternak untuk menjamin pertumbuhan dan kesehatan ayam yang dipelihara, namun di sisi lain dampak terhadap konsumen saat ini menjadi perhatian pemerintah. World Health Organization (WHO) telah melarang penggunaan AGP pada ternak karena dapat berakibat buruk bagi kesehatan manusia.

Akibat pelarangan penggunaan AGP maka produk-produk alternatif sebagai pengganti AGP atau alternative nature growth promoters (ANGP) telah banyak dikembangkan. Beberapa bentuk ANGP yang sudah dikenal diantaranya dalam bentuk asam organik, immunomodulator, prebiotik, probiotik, copper, fitogenik dan enzim. Semua produk tersebut berpotensi meningkatkan kesehatan saluran pencernaan dan performa pertumbuhan. Salah satu bentuk alternatif yang dapat digunakan dan berpotensi besar sebagai feed additive adalah probiotik dan fitobiotik.

Probiotik merupakan salah satu feed additive pakan yang dapat digunakan untuk mengoptimalkan produktivitas ternak secara efisien. Dhama et al. (2011) menyatakan bahwa probiotik merupakan cara alternatif menghemat biaya daripada menggunakan AGP, pada umumnya aman karena tidak menunjukkan adanya residu yang terbawa di telur atau daging. Sehingga tidak membahayakan kesehatan manusia, tidak seperti penggunaan antibiotik sebagai suplemen pakan atau promotor pertumbuhan. Selain itu juga dapat mengurangi pengeluaran dari terapi (obat-obatan/antibiotik). Penambahan probiotik ke dalam pakan ternak dapat mendorong pertumbuhan populasi mikroba yang tepat dalam usus unggas yang mampu untuk mengembangkan resistensi alami pada tubuh unggas untuk melawan berbagai patogen.

Probiotik merupakan jasad renik nonpatogen yang jika dikonsumsi dalam takaran cukup dapat bermanfaat bagi kesehatan dan fisiologi tubuh. Beberapa pengaruh positif dari probiotik bagi kesehatan antara lain hipokolesterolemik, yaitu membantu menurunkan kadar kolesterol dalam serum darah ternak. Bakteri probiotik merupakan bakteri hidup yang bila dikonsumsi oleh hewan atau manusia dapat memberikan efek kesehatan. Kral et al. (2012) mencoba menggunakan probiotik dalam pakan broiler strain Cobb dan menunjukkan hasil pertumbuhan yang nyata mulai pada ayam umur 5 minggu. Probiotik 
mampu menghasilkan senyawa antimikroba, yang menghambat pertumbuhan atau bahkan dapat membunuh bakteri patogen. Penggunaan probiotik cair telah dicoba oleh Agustina et al. (2007), pemberian probiotik cair (Lactobacilus sp.) tidak memberikan perbedaan nyata pada penampilan broiler perlakuan pemberian probiotik dengan tanpa diberi probiotik, meski demikian ada kecenderungan bahwa perlakuan P1 (2,5 cc/1 air minum) lebih baik secara biologis. Akan tetapi penggunaan probiotik berperan dalam menekan tingkat mortalitas broiler.

Fitogenik atau fitobiotik merupakan senyawa yang berasal dari tumbuhan, telah dimasukkan dalam pakan ternak unggas untuk meningkatkan produktivitas. Fitobiotik berbagai bahan tanaman, sebagian besar yang memiliki sejarah panjang dalam nutrisi manusia, telah digunakan sebagai rasa, pengawet makanan, dan obat-obatan, padat, kering, dan bentuk tanah atau sebagai ekstrak atau minyak esensial. Para saintis saat ini tengah fokus pada fungsionalitas dari jalur usus. Penekanan ini telah terjadi karena : 1) biaya bahan pakan dan keinginan untuk memaksimalkan pemanfaatan nutrisi (juga mengurangi emisi ke lingkungan); 2) perbaikan genetik, dimana minggu pertama setelah menetas atau menyapih (merupakan periode pertumbuhan kritis usus) mewakili proporsi yang lebih besar dari kehidupan unggas; dan 3) penghilangan subterapeutik antibiotik telah meningkatkan prevalensi patogen (termasuk patogen yang ditularkan melalui makanan), oleh karena itu, probiotik dan aditif pakan fitogenik mendapat perhatian. (Applegate et al., 2010).

Upaya mempertahankan produktivitas broiler pasca pelarangan AGP, memberikan kesempatan yang lebih luas penggunaaan bahan aditif alternatif yang tersedia. Pemanfaatan probiotik telah banyak dilaporkan memberikan dampak positif pada pertumbuhan broiler, demikian pula penggunaan bawang putih. Penggunaan kedua preparat aditif lokal tersebut tentunya akan memberikan kesehatan yang optimal broiler dan berujung pada produktivitas broiler sesuai potensi genetiknya. Namun disisi lain, pengembangan hasil ternak yang sehat untuk konsumen juga telah menjadi fokus dalam berbagai penelitian. Eksplorasi bahan aditif lokal seperti probiotik (bentuk mikroba lokal) yang dikombinasikan dengan keunggulan bawang putih (sebagai fitobitoik), tentunya akan menjadi keunggulan spesifik yang memberikan manfaat ganda bagi produktivitas broiler dan kesehatan konsumen. Efek metabolik yang terkandung dalam bawang putih (Allium sativum) dapat menurunkan gula darah, trigliserida, dan kolesterol darah (Horie et al., 1991). Senyawa Allicin yang terkandung dalam bawang putih mempunyai sifat mengikat bagian fungsional enzim KoA gugus sulfhidril guna biosintesis kolesterol (Nyoman, 1997). Syamsiah dan Tajudin, (2003) menambahkan bahwa selain allicin bawang putih juga mengandung senyawa skordinin yang berfungsi sebagai antioksidan yang dapat menekan kolesterol, meningkatkan daya tahan, memacu pertumbuhan dan mencegah kerusakan sel. Purwanti et al., (2015) melaporkan bahwa penambahan ransum dengan ekstrak air bawang putih 2,0\% mampu sebagai anti-bakteri dan dapat digunakan sebagai feed additive alternatif pengganti antibiotik sebagai pemacu pertumbuhan.

Berdasar uraian tersebut maka pada penelitian ini dilakukan eksplorasi terhadap bawang putih sebagai bahan fitobiotik yang difermentasi dengan mikroba lokal asal usus halus sapi yang digunakan sebagai suplemen untuk ayam broiler untuk mengetahui penampilan broiler, kualitas karkas, dan kualitas fisik daging ayam broiler.

\section{METODE}

Pemeliharaanayambroilerdilaksanakan selama 35 hari. Tempat pelaksanaan penelitian di kandang unggas Politeknik Negeri Jember. Alat yang digunakan dalam penelitian ini meliputi: kandang bersekat untuk broiler dan peralatan pemeliharaan, peralatan pembuatan 
profitobiotik, dan peralatan pemotongan ayam dan karkas ayam. Bahan yang digunakan dalam pelaksanaan penelitian ini meliputi: DOC broiler 200 ekor, pakan jadi BR1, obat vaksin kesehatan dan desinfektan. Bahan yang digunakan untuk pembuatan profitobiotik meliputi bawang putih, air, mikroorganisme lokal, gula merah, dan plastik.

Tahap pembuatan profitobiotik yaitu sebagai berikut. Pertama menyiapkan larutan air gula kelapa dari, pengukusan bawang putih yang telah dihancurkan pada suhu $60-$ $70^{\circ} \mathrm{C}$ selama 15 menit. Kukusan bawang putih dingin dicampur dengan mikroorganisme lokal yang berasal dari usus halus sapi dalam air gula kelapa, kemudian dimasukkan dalam wadah fermentasi yang tertutup rapat. Fermentasi dilakukan selama 7 hari dan dikocok 3-4 kali setiap hari. Setelah 7 hari, campuran hasil fermentasi disaring dan siap menjadi bahan profitobiotik untuk unggas.

Tahap persiapan kandang yaitu meliputi sanitasi kandang dan peralatan, pemberian kapur pada dinding dan lantai kandang, penyemprotan desinfektan, istirahat kandang, dan pembuatan sekat. Kandang yang digunakan merupakan kandang litter sebanyak 20 unit percobaan. Setiap unit percobaan berukuran $1 \times 1 \mathrm{~m}^{2}$. Sepuluh ekor ayam ditempatkan pada setiap unit percobaan. Guna menyamakan suhu, kelembapan, dan pencahayaan maka pada kandang dilakukan penutupan menggunakan tirai dalam dan tirai luar pada ventilasi kandang.

Rancangan percobaan yang digunakan dalam percobaan menggunakan Rancangan Acak Lengkap (RAL) dengan 4 perlakuan sebagai berikut:

P0 : Pemberian Profitobiotik $0 \mathrm{ml}$ dalam air minum

P1 : Pemberian Profitobiotik $2 \mathrm{ml} /$ liter air minum

P2 : Pemberian Profitobiotik $4 \mathrm{ml} /$ liter air minum

P3 : Pemberian Profitobiotik $6 \mathrm{ml} /$ liter air minum

Masing-masing perlakuan diulang sebanyak lima kali, sehingga terdapat dua puluh unit percobaan. Setiap unit percobaan diisi sepuluh ekor broiler. Pemberian profitobiotik dengan air minum mulai umur 15 hari - 35 hari (panen). Penempatan ayam broiler pada setiap unit percobaan dilakukan secara acak. Parameter pengamatan dalam penelitian meliputi penampilan broiler (konsumsi pakan, pertambahan bobot badan, konversi pakan), karkas, persentase lemak abdominal, persentase hati, dan kualitas fisik daging broiler (susut masak, daya ikat air, tekstur/keempukan, dan $\mathrm{pH}$ ).

Kualitas fisik daging broiler meliputi:

- Uji nilai $\mathrm{pH}$ menggunakan metode Ockerman (1983).

- Uji Daya Ikat Air (DIA), yaitu kapasitas daya ikat air oleh protein daging dapat ditentukan menggunakan metode sentrifus, dihitung dengan menggunakan rumus sebagai berikut.

$$
\% D I A=\frac{\text { Vol.air yang ditambahkan }- \text { Vol. air sisa }}{\text { Berat sampel }(\text { gram })} \times 100
$$

- Uji Keempukan, diukur dengan menggunakan Penetrometer.

- Susut Masak (cooking loss), dihitung mengunakan rumus sebagai berikut (Suparno, 2005).

$$
\% \text { Susut Masak }=\frac{\text { Berat Awal }- \text { Berat Akhir }}{\text { Berat Akhirl }(\text { gram })} \times 100
$$

Analisis Data dengan uji ANOVA (Analysis of Variance) atau analisis sidik ragam menggunakan program Statistical Package for the Social Sciences (SPSS) 16. Uji lanjut dilakukan pada data yang menunjukkan berbeda nyata menggunakan uji Beda Nyata Terkecil (BNT) taraf 5\% dan $1 \%$.

\section{HASIL DAN PEMBAHASAN}

\section{Penampilan Broiler}

Hasil analisis sidik ragam menunjukkan bahwa pemberian profitobiotik memberikan pengaruh yang tidak nyata $(\mathrm{P}>0,05)$ terhadap 
JPI Vol. 23 (1): 74-81

Tabel 1. Pengaruh profitobiotik terhadap penampilan broiler

\begin{tabular}{lccc}
\hline Perlakuan & $\begin{array}{c}\text { Konsumsi Pakan } \\
(\mathrm{g} / \mathrm{ekor})\end{array}$ & $\begin{array}{c}\text { Pertambahan Bobot Badan } \\
(\mathrm{g} / \mathrm{ekor})\end{array}$ & Konversi Pakan \\
\hline P0 & $3199,99^{\text {ns }}$ & $1872,74^{\text {ns }}$ & $1,71^{\text {ns }}$ \\
P1 & $3276,62^{\text {ns }}$ & $1920,54^{\text {ns }}$ & $1,71^{\text {ns }}$ \\
P2 & $3256,87^{\text {ns }}$ & $1925,06^{\text {ns }}$ & $1,69^{\text {ns }}$ \\
P3 & $3284,17^{\text {ns }}$ & $1903,51^{\text {ns }}$ & $1,73^{\text {ns }}$ \\
\hline
\end{tabular}

Keterangan: notasi yang sama menunjukkan perlakuan memberikan perbedaan pengaruh yang tidak nyata $(\mathrm{P}>0,05)$

penampilan broiler. Hal ini menunjukkan bahwa pemberian profitobitik menghasilkan respon yang sama pada broiler. Profitobiotik yang dibuat dari fermentasi bawang putih dengan probiotik asal usus halus sapi tidak mengubah penampilan ayam dan memberikan produktivitas broiler yang tidak berbeda.

Penampilan broiler pada masingmasing perlakuan menunjukkan tingkat konsumsi pakan antara 3199,99 - 3284,17 g/ekor, kemudian pertambahan bobot badan antara 1872,74-1925,06 g/ekor, dan efisiensi pakan antara 1,69-1,73 (Tabel 1). Kondisi ini juga dapat diartikan bahwa penggunaan jenis profitobiotik ini dan juga dosis yang diberikan tidak mengganggu kesehatan ayam. Meskipun pada perlakuan P1, P2, dan P3 terdapat kecenderungan konsumsi pakan dan pertambahan bobot badan yang lebih tinggi dibanding $\mathrm{P} 0$, namun peningkatan tersebut belum memberikan hasil yang nyata. Hal ini juga didukung dengan nilai konversi pakan semua perlakuan yang tidak berbeda. Berdasar hasil tersebut, dalam hal penampilan broiler, maka produk profitobiotik yang dibuat masih perlu dilakukan peningkatan dosis pemberian yaitu lebih dari $6 \mathrm{ml}$ per liter air minum.

Persentase: Karkas, Lemak Abdominal, dan Hati

Hasil analisis sidik ragam menunjukkan bahwa pemberian profitobiotik memberikan hasil yang tidak berbeda nyata $(\mathrm{P}>0,05)$ terhadap persentase karkas dan hati broiler, sedangkan pada persentase lemak abdominal memberikan hasil yang berbeda nyata $(\mathrm{P}<0,05)$ (Tabel 2). Rataan bobot hidup dan berat karkas broiler, rataan bobot badan dan berat karkas yang tidak berbeda menghasilkan persentase karkas yang tidak berbeda pula, namun persentase lemak abdominal pada P1, P2, dan P3 berbeda dengan P0. Hal ini menunjukkan bahwa pemberian profitobiotik mampu menekan terbentuknya lemak jenuh dalam tubuh broiler. Namun dengan dosis 2, 4, dan $6 \mathrm{ml}$ per liter air minum belum menunjukkan perbedaan. Aspek positif yang di dapat dengan hasil tersebut, profitobitotik yang diberikan pada broiler tidak mengganggu kesehatan broiler dan mampu menurunkan lemak abdominal, dimana hal ini mengindikasikan juga kandungan lemak dalam daging. Dapat diduga bahwa kombinasi probiotik dan fitobiotik menghasilkan bahan aktif mampu meningkatkan efisiensi pencernaan lemak.

Persentase hati yang tidak berbeda pada broiler yang diberikan pada broiler menunjukkan bahwa dengan dosis 2, 4, dan $6 \mathrm{ml}$ per liter air minum memberikan respon yang baik, tidak menunjukkan pembengkakan hati pada P1, P2, dan P3 bila dibandingkan dengan P0. Pembesaran atau pembengkakan hati dapat disebabkan racun yang terbawa oleh makanan atau minuman (Manuaba et al., 2017). Sedangkan ukuran, berat, konsistensi dan warna hati tergantung dari bangsa, umur dan status nutrisi individu ternak (Budiman et al., 2015).

\section{Kualitas Fisik Daging Broiler}

Hasil pengamatan menunjukkan bahwa pemberian profitobiotik menghasilkan nilai susut masak dan daya ikat air yang tidak berbeda nyata $(\mathrm{P}>0,05)$ akan tetapi 
Tabel 2. Pengaruh profitobiotik terhadap penampilan persentase karkas, lemak abdominal, dan hati ayam broiler

\begin{tabular}{cccccc}
\hline Perlakuan & $\begin{array}{c}\text { Bobot Hidup } \\
(\mathrm{g} / \text { ekor })\end{array}$ & $\begin{array}{c}\text { Berat Karkas } \\
(\mathrm{g} / \text { ekor })\end{array}$ & $\begin{array}{c}\text { Karkas } \\
(\%)\end{array}$ & $\begin{array}{c}\text { Lemak Abdominal } \\
(\%)\end{array}$ & $\begin{array}{c}\text { Hati } \\
(\%)\end{array}$ \\
\hline P0 & $1928,20^{\text {ns }}$ & $1399,10^{\text {ns }}$ & $72,56^{\text {ns }}$ & $1,78^{\text {b }}$ & $2,13^{\text {ns }}$ \\
P1 & $1960,00^{\text {ns }}$ & $1389,30^{\text {ns }}$ & $70,87^{\text {ns }}$ & $1,50^{\text {a }}$ & $2,16^{\text {ns }}$ \\
P2 & $1907,90^{\text {ns }}$ & $1363,60^{\text {ns }}$ & $71,40^{\text {ns }}$ & $1,74^{\text {a }}$ & $2,03^{\text {ns }}$ \\
P3 & $1944,00^{\text {ns }}$ & $1379,40^{\text {ns }}$ & $70,96^{\text {ns }}$ & $1,54^{\text {a }}$ & $2,14^{\text {ns }}$ \\
\hline
\end{tabular}

Keterangan: notasi yang sama (kolom Bobot Hidup, Berat Karkas, \%Karkas, dan \% Hati) menunjukkan perlakuan memberikan perbedaan pengaruh yang tidak nyata $(\mathrm{P}>0,05)$; notasi yang berbeda (kolom \% Lemak Abdominal) menunjukkan perlakuan memberikan perbedaan pengaruh yang berbeda nyata $(\mathrm{P}<0,05)$

memberikan hasil yang berbeda sangat nyata $(\mathrm{P}<0,01)$ terhadap tekstur dan $\mathrm{pH}$ daging. Susut masak daging broiler pada penelitian ini menunjukkan nilai antara $34,86-36,38 \%$, hasil ini menunjukkan nilai susut masak yang cukup besar. Susut masak merupakan salah satu indikator kualitas daging, nilai susut masak yang semakin besar maka akan semakin banyak air dalam daging yang hilang dan hal ini akan berhubungan dengan nutrisi daging yang hilang bersama air. Uji susut masak digunakan untuk memprediksi jumlah kandungan cairan dalam daging masak (Soeparno, 2005). Daging yang susut masaknya lebih rendah mempunyai kualitas fisik relatif lebih baik daripada daging dengan susut masak lebih tinggi, karena daging yang susust masaknya rendah kehilangan nutrisi selama pemasakan lebih sedikit. Hasil penelitian Suradi (2006) menunjukkan bahwa susut masak daging setelah 12 jam pemotongan adalah sebesar $34,76 \%$. Seperti yang ditampilkan pada Tabel 3 , pada P3 menunjukkan kecenderungan nilai susut masak yang lebih baik.

Tekstur daging pada dasarnya akan berhubungan dengan kondisi keempukan daging, dan istilah keempukan mungkin menjadi istilah yang lebih dipahami oleh konsumen. Keempukan dan tekstur daging merupakan paremeter penting dalam kualitas daging (Soeparno, 2005). Keempukan daging ditentukan oleh besarnya tekanan yang dibutuhkan untuk tiap satuan luas $\left(\mathrm{kg} / \mathrm{cm}^{2}\right)$ produk, semakin kecil angka yang diperoleh maka semakin empuk daging tersebut. Hasil pengamatan menunjukkan bahwa P3 menghasilkan nilai keempukan yang paling tinggi dan berbeda dengan perlakuan lainnya. Hal ini menunjukkan bahwa pemberian profitobiotik pada dosis $6 \mathrm{ml}$ per liter air menghasilkan daging yang lebih keras. Dengan demikian daging broiler pada P3 mempuyai jaringan kolagen yang lebih kuat dibandingkan dengan perlakuan lainnya meskipun di potong pada umur yang sama. Jaringan ikat merupakan faktor penting dalam penentuan keempukan daging (Lawrie, 1995). Jumlah dan kekuatan kolagen dapat meningkat seiring pertambahan umur, ikatan silang kovalen meningkat selama pertumbuhan dan perkembangan ternak dan kolagen menjadi lebih kuat (Soeparno, 2005).

Analisis sidik ragam juga menunjukkan nilai daya ikat air yang tidak berbeda di antara perlakuan. Nilai yang diperoleh adalah antara $39,61-40,77 \%$. Hasil ini merupakan nilai daya ikat air yang cukup besar. Menurut Soeparno (2005), daya ikat air berhubungan dengan protein, molekul-molekul air bebas yang jumlahnya sekitar $10 \%$ terikat di antara molekul protein akan menurun ketika protein daging mengalami denaturasi. Jenis kelamin berpengaruh yang kecil terhadap susut masak pada umur yang sama, akan tetapi berat potong dapat berpengaruh nyata terhadap susut masak khususnya jika terdapat perbedaan deposit lemak. 
JPI Vol. 23 (1): 74-81

Tabel 3. Pengaruh profitobiotik terhadap kualitas fisik daging ayam broiler

\begin{tabular}{ccccc}
\hline Perlakuan & $\begin{array}{c}\text { Susut Masak } \\
(\%)\end{array}$ & $\begin{array}{c}\text { Tekstur } \\
(\mathrm{kg} / \mathrm{cm})\end{array}$ & $\begin{array}{c}\text { Daya Ikat Air } \\
(\%)\end{array}$ & $\mathrm{pH}$ \\
\hline P0 & $36,18^{\mathrm{ns}}$ & $12,88^{\mathrm{b}}$ & $40,77^{\mathrm{ns}}$ & $5,80^{\mathrm{b}}$ \\
P1 & $36,38^{\mathrm{ns}}$ & $10,38^{\mathrm{a}}$ & $39,61^{\mathrm{ns}}$ & $5,47^{\mathrm{a}}$ \\
P2 & $36,03^{\mathrm{ns}}$ & $12,30^{\mathrm{a}}$ & $40,59^{\mathrm{ns}}$ & $5,18^{\mathrm{a}}$ \\
P3 & $34,86^{\mathrm{ns}}$ & $13,66^{\mathrm{c}}$ & $40,67^{\mathrm{ns}}$ & $5,19^{\mathrm{a}}$ \\
BNT & - & - & - & \\
\hline
\end{tabular}

Keterangan: notasi yang sama (kolom Susut Masak dan Daya Ikat Air) menunjukkan perlakuan memberikan perbedaan pengaruh yang tidak nyata $(\mathrm{P}>0,05)$; notasi yang berbeda (kolom Tekstur dan $\mathrm{pH})$ menunjukkan perlakuan memberikan perbedaan pengaruh yang berbeda sangat nyata $(\mathrm{P}<0,01)$

\section{KESIMPULAN}

Berdasarkan penelitian diperoleh kesimpulan bahwa profitobiotik dalam bentuk bawang putih terfermentasi probiotik usus halus sapi tidak menunjukkan pengaruh nyata terhadap penampilan broiler, persentase karkas, persentase hati, susut masak, daya ikat air. Pengaruh yang nyata ditunjukkan pada persentase lemak abdominal dan tekstur (keempukan) daging broiler. Penggunaan profitobiotik aman digunakan untuk broiler serta cenderung menghasilkan daging yang lebih kesat. Diperlukan penelitian lebih lanjut pada dosis penggunaan yang lebih tinggi untuk melihat pengaruhnya pada penampilan broiler.

\section{UCAPAN TERIMA KASIH}

Peneliti mengucapkan terima kasih atas dukungan dana penelitian dari Politeknik Negeri Jember melalui pendanaan PNBP sehingga penelitian ini dapat dilakukan dengan baik.

\section{DAFTAR PUSTAKA}

Agustina, L., Purwanti, S. dan Zainuddin, D. 2007. Penggunaan probiotik (Lactobacillus sp.) sebagai imbuhan pakan broiler. Seminar Nasional Teknologi Peternakan dan Veteriner
2007.

Applegate, T. J., Klose, V., Steiner, T., Ganner, A. and Schatzmayr, G., 2010. Probiotics and phytogenics for poultry: Myth or reality?.J. Appl. Poult. Res. 19 :194-210.

BPS. 2019. Populasi Ayam Ras Pedaging menurut Provinsi, 2009-2019. https:// www.bps.go.id/linkTableDinamis/ view/id/1034. Diakses pada 20 Maret 2020

Budiman, H., T. R. Ferasyi., Tapielaniari., M. N. Salim., U. Balqis, dan M. Hambal. 2015. Pengamatan lesi mikroskopis pada hati ayam broiler yang dijual di pasar lambaro aceh besar dan hubungannya dengan keberadaan mikroba. Jurnal Medika Veterinaria 9(1): $51-53$.

Dhama, K., Verma, V., Sawant, P. M., Tiwari, R., Vaid, R. K., and Chauhan, R. S. 2011. Applications of probiotics in poultry: enhancing immunity and beneficial effects on production performances and health - A Review. Journal of Immunology and Immunopathology. 13(1): 1-19.

Horie, T., S. Awazu., Y. Itakura, and T. Fuwa. 1991. Identified diallyl polysulfides from an agedgarlic extract which protect the membranes from lipid peroxidation. J. Planta Medica.58: 468-469. 
Kral, M., Angelovicova, M. and Mrazova, L. 2012 Application of probiotics in poultry production. Scientific Papers: Animal Science and Biotechnologies, 45(1).

Lawrie, R. A. 1995. Ilmu Daging. Edisi ke 5. Terjemahan: A. Parakkasi. UI Press, Jakarta.

Manuaba, I. B., N. W. Siti, dan N. M. S. Sukmawati. 2017. Pengaruh aditif sari daun pepaya terfermentasi terhadap organ dalam ayam kampung. Journal of Tropical Animal Science. 5(1): 37-49.

Nyoman, I. S. 1997. Pengaruh penambahan bawang putih (Allium sativum) dalam pakan pada kadarkolesterol ayam broiler. Tesis. Program Pasca Sarjana, Institut Pertanian Bogor. Bogor.

Ockermen, H. W. 1983. Chemistry of Meat Tissue. 10th Edit. Dept of Animal Science. The Ohio State University and The Ohio Agricultural
Research and Departement Centre, Ohio.

Soeparno. 2005. Ilmu dan Teknologi Daging. Gadjah Mada University Press, Yogyakarta.

Suradi, K. 2006. Perubahan sifat fisik daging ayam broiler post mortem selama penyimpanan temperatur ruang. Jurnal Ilmu Ternak, 6(1): 23 - 27.

Syamsiah, I. S. dan Tajudin. 2003. Khasiat dan Manfaat Bawang Putih. Agromedia Pustaka, Jakarta.

Purwanti, S., Zuprizal, dan Yuwanta, T. 2015. Efektivitas pemanfaatan fitobiotik ekstrak air kunyit dan bawang putih sebagai feed additive untuk meningkatkan kualitas gastrointestinal, kinerja produksi, dan kualitas daging broiler. Disertasi Program Pascasarjana Peternakan. Universitas Gadjah Mada, Yogyakarta. 